\title{
TENAGEER BEHAVIORS AND TEENAGER PREGNANCIES IN LIMAKOLI VILLAGE, ROTE NDAO DISTRICT, EAST NUSA TENGGARA PROVINCE, INDONESIA
}

\author{
(Perilaku Remaja dan Kehamilan Remaja di Desa Limakoli, \\ Kabupaten Rote Ndao, Provinsi Nusa Tenggara Timur, Indonesia)
}

\author{
Betty Roosihermiatie ${ }^{1}$, Indah Nur Esti Leksani2 ${ }^{2}$ Oktarina $^{3}$, Marizka Khairunnisa ${ }^{4}$ \\ ${ }^{1}$ Center of Research and Development for Humaniora and Health Management, NIHRD, Ministry of Health \\ the Republic of Indonesia \\ 2 Faculty of Public Health, Airlangga University, Surabaya \\ 3 The Unit Innovation of Health Technology, Center of Research and Development for Humaniora and Health \\ Management, NIHRD, Ministry of Health the Republic of Indonesia \\ ${ }^{4}$ Center for Research and Development Magelang, NIHRD, Ministry of Health the Republic of Indonesia
}

Naskah masuk: 23 Juni 2020 Perbaikan: 21 November 2020 Layak terbit: 7 Desember 2020

https://doi.org/10.22435/hsr.v23i4.3386

\begin{abstract}
Young marriage still occur in Indonesia. About $0.2 \%$ (22,000) teenager 10-14 years were married. Though, Law of marriage the Republic of Indonesia on age requirements are 19 years for men and 16 years for women. Two things for unexpected pregnancy are maintaining or ending a pregnancy by adolescents. The study aimed to determine teenager behaviors and teenager pregnancies in Limakoli village, Rote Ndao District. It was an explorative ethnographic. Inforrmants were selected by snowball sampling. Data were analyzed by thematic analysis. Girls used to do houseworks. Meanwhile, boys had sports in the afternoon. Tenageers got knowledge and information on reproductive health but discussions of pregnancy and the risks were limited. The pregnant teenagers faced gossips and social stigma. One teen pregnacy was faced angry by their parents and families, aborted, quiet, drop out from school. The other teenager covered her second pregnancy, though her parents likely accept her pregnancy. Teenager pregnancies tended not to have antenatal cares. The traditional marriage 'Terang Kampung' was not done by underages, likely it included family and extended families. Pregnant teenagers dropped out from schools, in contrast boys did not. Girls had most impact on teenager pregnancies of physical, psychological, and social risks. Hence, an integrative sociocultural intervention for dating with no sexual relations, no adolescence pregnancies and marriage by school, church, primary health center, traditional leaders, village staffs should be developed.
\end{abstract}

Keywords: Tenageers, pregnancy, risks, behaviors

\begin{abstract}
ABSTRAK
Pernikahan muda masih terjadi di Indonesia. Sekitar 0,2\% (22.000) remaja 10-14 tahun menikah. Padahal, UU Perkawinan Republik Indonesia tentang persyaratan usia adalah 19 tahun untuk pria dan 16 tahun untuk wanita. Dua hal untuk kehamilan yang tak terduga adalah mempertahankan atau mengakhiri kehamilan oleh remaja. Penelitian ini bertujuan menentukan perilaku remaja dan kehamilan remaja di Desa Limakoli, Kabupaten Rote Ndao. Studi ini adalah etnografi eksploratif. Informan dipilih secara snowball sampling. Data dianalisis dengan analisis tematik. Remaja perempuan biasanya melakukan pekerjaan rumah. Sementara, remaja laki-laki berolahraga di sore hari. Remaja memperoleh pengetahuan dan informasi tentang kesehatan reproduksi, tetapi diskusi tentang kehamilan dan risikonya terbatas. Remaja yang hamil menghadapi gosip dan stigma sosial. Seorang remaja hamil menghadapi kemarahan orang tua dan keluarganya, mengalami aborsi, menjadi pendiam, dan putus sekolah. Remaja lainnya menutupi kehamilannya yang kedua, walaupun kemungkinan orang tuanya menerima kehamilannya. Kehamilan remaja cenderung tidak mendapat antenatal care. Perkawinan tradisional 'Terang Kampung' tidak dilakukan oleh anak-anak di bawah umur, kemungkinan
\end{abstract}

Corespondence:

Betty Roosihermiatie

Center of Research and Development for Humaniora and Health Management, NIHRD, Ministry of Health the Republic of Indonesia

E-mail: roosihermiatie@yahoo.com 
karena melibatkan keluarga dan keluarga besar. Remaja yang hamil mengalami drop out dari sekolah, sebaliknya remaja laki-laki tidak. Remaja perempuan memiliki dampak paling besar pada kehamilan remaja terhadap risiko fisik, psikologis, dan sosial. Sehingga perlu dikembangkan, intervensi sosiokultural integratif untuk berpacaran tanpa hubungan seksual, tidak ada kehamilan remaja dan pernikahan, dengan melibatkan sekolah, gereja, pusat kesehatan primer, pemimpin tradisional, staf desa.

Kata Kunci: Remaja, kehamilan, risiko, perilaku

\section{INTRODUCTION}

In Indonesia still occurs early marriage and adolescent pregnancy. The Law of Indonesia No. 1 of 1974 on age requirements for marriage are 19 years for men and 16 years for women, respectively. Though in some areas, applications for marital dispensation is filed to the Religious Court in the applicant's legal territory for under age teenagers by both prospective parents. The dispensation of the court is given when there is an urgent situation even if the prospective bride under aged, as the bride is pregnant.

Adolescent pregnancy is not a new phenomenon, still it is an important global health issue. Adolescent pregnancy means the pregnancy between 11-19 years old (WHO, 2004). Based on Basic Health Research (Riskesdas) Indonesiain 2008, 0.2\% $(>22,000)$ young women aged 10-14 years were married (Badan Litbangkes, 2008). And there was $11.7 \%$ young women aged $15-19$ who married or $0.1 \%$ higher than young men who married at the same ages. Meanwhile, the Basic Health Research (Riskesdas) Indonesia in 2013 showed the proportion of pregnancies among aged 15-19 years old was 2.6\% (Badan Litbangkes, 2015). The Indonesian Demographic and Health Survey 2017 showed 2\% of women and $8 \%$ of men aged $15-24$ years said they had sexual relationship before marriage. Whereas the highest $(74 \%)$ of the first sexual intercourse was of 15-19 year age. Adolescents are the highest who have the first sexual intercourse before married. Furthermore, the IDHS showed 36 per 1000 women give birth in their teens (15-19 years), and 27 per 1000 women in East Nusa Tenggara Province (BKKBN, BPS and Kementerian Kesehatan, 2018).

Adolescent pregnancies risk women because they are not mature physically and emotionally. The pregnancy itself can also have a physical, psychological, and social impacts. Pregnant women at an early age are at risk of miscarriage, anemia of pregnancy, bleeding, and maternal mortality. The adolescent pregnancy is highly risk of getting pregnancy and birth complications, being one of the main causes of maternal deaths (WHO, 2004).
Teenager pregnancies relates to unwanted pregnancies, and many of them end in attempts of abortion caused by shame and worried about getting social sanctions. Based on the IDHS in 2017, the unwanted pregnancy among women was $12 \%$ in which $16 \%$ of them was $15-19$ years old (BKKBN, BPS and Kementerian Kesehatan, 2018). For developed regions pregnant teenagers tend to be unmarried, whereas in developing countries including Indonesia, the pregnant teenagers are often married and their families and societies might accept their pregnancy (Soejoenoes, 2017).

Romauli stated there are two things that can and are usually done if you experience an unexpected pregnancy, either maintaining or ending a pregnancy (Romauli, Suryati, 2011). When the pregnancies are terminated (abortion), it can result in negative conditions including risks of bleeding, overdraft walls of the uterus if currying too deep, menstrual disorders if reaching muscle membranes, and infection.

The pregnant teenagers also face a social economic risk, like poor educational outcomes due to school dropout, impact in limited livelihood option and economic independence (Mccleary-sills et al., 2013). In Rote Ndao District, East Nusa Tenggara Province there was traditional marriage with under age married. Studies on tenageer pregnancies in Rote Ndao District was very few. Hence, the study aimed to determine teenager behaviors and teenager pregnancies in Limakoli village, Central Rote, Rote Ndao District, East Nusa Tenggara Province.

\section{METHODS}

The study was an exploration design with an ethnography approach, which describing a culture to understand the view of life from the perspective of indigenous people (Spradley, 2007). It was part of a study about maternal health in Rote Tribe year 2014. The study was carried out in Rote Ndao District, East Nusa Tenggara Province because of severe/ poor health problem categories (rank 401 district) ofthe Public Health Development Index (PHDI) 2007. 
Moreover, Rote Ndao Districtranked the $12^{\text {th }}$ of the PHDI among 14 districts in the Province.

The study population were people in Limakoli village. The informants were indigenous residents. They were selected by snowball sampling based on the criteria: culturally involved, understand information and can provide information related to the study topics. The informants included teenagers, parents, families, neighbors; community leaders, religious leaders, or traditional leaders who know the local culture; traditional birth attendants; and health workers.

The study was done for 50 days, in which researchers were living in the study location. Data were collected by in-depth interview by semi structured interview guides. An interview per informant was for 30 - 60 minutes.

Data were analyzed by thematic analysis on teenager behaviors of teenager daily activities, teenager leisure times, teenager traditional alcohol drinking habit, teenager access to handphone and also teenager pregnancies of teenager knowledge of reproductive health, teenager dating, menstruation, reproductive health education and teenager pregnancy cases of teenager pregnancies's risk, teenager antenatal care, teenager pregnancies outcome. Researchers read transcripts of the interviews for codings and themes for analysis.

The study had ethical clearance from the Commette of Ethics, NIHRD, MOH of Indonesia.

\section{RESULTS}

Limakoli village was located $\pm 20 \mathrm{~km}$ from Ba'a, the capital of district. Access to the Limakoli village was good, although some parts of road were badly damaged. There were public transportation (motorcycles or pickups) from the capital to next village passing village Limakoli on weekly market day.

Rote etnics has patrileneal kinship system which follows the father's bloodline for family name's clan, called fam.The majority of religion in Limakoli village were Catholic. For education, about half of Limakoli residents were elementary school and the rest were junior/senior high school. Few were graduated to universities. Most villagers were farmers, planting rice and grow vegetables.

The Primary Health Center (PHC) was at the capital of the subdistrict. It can be reached about 30 minutes by vehicles. Every month, there was
Integrated Service Post for under five children and pregnant woman health services done by health cadres and a village midwife.

\section{Teenager Behavior in Limakoli Village}

Adolescence is a transition period from child to adult (WHO, 2006). Adolescents have growth and psychological developmentsfrom childhood to adults, whiletheir body and waysof thinking are not like children anymore, yet they are not mature adults. In Limakoli village, there was no tradition that mark the transition from childhood to adolescence. There was no circumcition among boys. The only ritual that marks the childhood to adolescence transition was a baptism that usually done for $15-18$ years old.

Most teenagers in Limakoli village were students. There was an elementary school in the village, whereas junior/senior high schools were in neighboring village. High school students used to walk to schools for about 30 minutes or living in the neighboring village. After school, girls used to help their parents' housework, such as cooking, washing dishes and clothes, carrying water from well, cleaning houses, or collecting firewood from forest. They did the task since 5-6 years and were responsible for all of housework at about 12 years. This time, their mothers would worked in fields. For boys were not burdened housework. In the afternoon, they usually played volleyball at the elementary school field. Boys were taught many kinds of work in fields during holidays.

Some boys had habit of traditional alcohol drinking, 'Sopi' was fermented from 'Nira' palm trees. 'Sopi' could be bought just at a shop in the village Rp. 0,000,- for $600 \mathrm{ml}$. They shared with their friends to pay, so was not expensive. It was common to see teenagers drinking 'Sopi' at marriage parties, death events, or when they were gathering at night. There was a drinking case of 16 year old teenager. During the study, a 14 year junior high school student was found drinking 'Sopi'with his two friends at a roadside in one afternoon.

"We do this every day, since a long time. After playing football in late of afternoon, we decide a time and place to drink tonight,"Nd.

Drinking 'Sopi' was not considered good behaviour for teenagers. However, none of the village officials, community leaders, traditional leaders, or community had action. 'Sopi' is believed as a part of tradition, not such violation of norms. There are 
no sanctions for teenagers who drink 'Sopi', unless they caused violation in community, such stealing, fighting, or making commotion after drinking.

"In the beginning, the village head said you could drink, but don't make damages to people's yards, as cut other's papaya, sweet potatoes. It is called stealing. Then, there must be sanctions. But if you just drink at a road, it might be OK ... "Nd repeated the village head warning to him.

Another thing that influence teenagers' activities were mobile phones. The informants said mobile phones influenced youth behaviors. Although mobile phones were considered luxurious devices, almost every family in the village had phones. The mobile phones were becoming part of teenager daily lives, as some school children in the village owned mobile phones. A junior high school teacher living in the village said that besides environments, mobile phones were influential for teenagers who tended to live freely.

"Yes, both surrounding and mobile phone. Well, on your mobile phone, is there a porn movie that you watch too? Nowadays, many junior high school students have mobile phones. And they have the sophisticated one, with camera. So they were affected. Even the first influences still coming from surrounding," said Lr.

Informants said teenagers were watching pornographic movie from VCD, downloading from internet, or browsing from their mobile phones. These influenced the environment that causes promiscuity behaviors on teenagers. The priest's wife ever scolded workers of a dam project in Limakoli village who made bad influences by showing porn videos from mobile phones to children surrounding during break times.

These caused parents feeling anxious, but they said could not fully control their children. Being farmers made them to leave home early and back in the evening. During parents' working, children were free to hang out with their friends.

"They play with their friends. Then they said 'I have a good films'. Apparently it is a porn movie, and they were watching it together, almost everyday, without the parents knowing. Their future is ruined," DK

The phenomenon was also being concerned by the priest in Limakoli village. He also alluded this on the sermon, as told parents so that their children not to take mobile phones at all. He said, nowadays mobile phones gave big contribution on teenager relationships.

\section{Teenager Pregnancies in Limakoli Village Teenager Knowledge on Reproductive Health}

Most teenager informants said they were interested in the opposite sex since junior high school. It was when most boys experienced wet dreams and girls had the first menstruation. Girls usually talked about persons they like just to their closest friends. Not all teenagers had courage to express their feelings to whom they like. But some dared to date, even had sexual relations.

Adolescents got knowledge about reproductive health from schools. Teachers taught about differences between men and women, and little information on menstruation at the sixth grade of elementary school. For junior/high school students had Biology lesson about reproductive organs. Teachers mentioned better not doing bad things and be careful dealing with the opposite sex. A junior high school student mentioned her teacher explained that a girl who had been menstruating could be pregnant, if having sexual relations.

"... I explained that when I had menstruated, the pubic signs functioned to have a reproduction ..." explained St.

The church provided information about reproductive health for teenagers on Sunday morning class. The PHC had routine activities at schools consisted of health counseling and providing tetanus immunization. For the PHC and Family Planning Office staff gave reproductive health counseling for junior/senior high school students.

"... The reproductive organs is part of family planning counseling material. The early signs of maturity are given in the counseling, "explain $K p$.

Mothers adviced their daughters related menstruation taboo and self protection. Every girl who had menstruation, had to obey self protection as avoiding negative association. One informant's parent told her child if a girl had had menstruation, she could not bring a man to her room. However, the mother did not give further explanation. The mothers had taboos as beliefs related to menstruation. When a girl is in her period, she should not take a shower in the evening because could have stomachache and 
excessive menstruation. If a woman is shampooing during menstruation period, it is believed that "white blood" will go to head which causes headaches, fainting, or the most fatal could be crazy.

The other mother explained her daughter after the first menstruation. It was a sign that she had entered adolescence. She also warned her daughter to look after herself and protected her daughter from dating. The informant also explained if someone having sexual relation within three days after menstruation so at higher risk to be pregnant.

"I said you should always try to keep a distance with a man. If I caught you for dating, then it means you'll quit from school. If teenager start dating and can't hold themselves in getting along with the opposite sex, if they were not be careful, she could be pregnant." DK

However, boys did not have much advice about sexual relations or beliefs on reproductive health from their parents. They got reproductive health information from peers or television. The PHC data showed no Sexually Transmitted Infections and HIVAIDS cases in Limakoli village.

\section{Teenager Pregnancy Cases in Limakoli Village}

One of teenager health problems was pregnancy out of wedlock at school age, mostly during junior/ senior high school. The ideal ages for marriage in Limakoli village were about 17 years old or an average of 15-16 years old for women and 16-19 years old for men, resectively. There are several underage marriages of 13-15 years old, either because of pregnancy or not. These caused high drop out, either for girls or boys. For the school rules, pregnant students had to quit schools.

"I have a niece who wants to get married. She was at third grade of senior high school and she will have a final exam soon. But she must drop out from the school. I didn't tell others but give the example of my own niece," Mn.

Under age marriage must get approval statement from their parents, if not the head of village will be blamed for breaking the government rules. Here, three pregnant teenagers informants of one who aborted her pregnancy, one who was in second pregnancy, and one who then had traditional marriage Terang Kampung, respectively.

Ss was a 16 year old senior high school student, living at dorm room since her school was far. She was pregnant with her school mate. As the school rules, she was dismissed during her pregnancy. After giving birth, she was back to school and living at dorm room again. Meanwhile, her child was given her parents' family name, considered their own child and raised for by her parents. Not so long, she was repregnant with her junior friend. She was dismissed again from the school. On her second pregnancy, SS's had antenatal care by the village midwife visit. She had the first ANC at five month pregnancy. During the study, she was at seven month pregnancy. According to the village midwife, SS's was not willing out of the room when the midwife visited at the third semester.

The other case was a teenage abortion. El a 17 year old teenager at second year of senior high school. She got pregnant with a married man, above her age. Her parents and extended family were angry with her pregnancy. They even threatened to killed her. She went to her brother's house in neighboring village because so fear. There, El bought headache powder at a kiosk for abortion intention. After taking the powder, she had stomachache and bleeding. Then, her family took her to the PHC and the examination revealed that her fetus could be saved. After returning home, hermother took her to a traditional healer to massage her stomach, then the fetus was aborted.

The third case, TI got pregnant at the third grade of junior high school, so she dropped out from school. Then, she had Terang Kampung marriage to a senior high school student. During the study, she was expecting her childbirth. The Terang Kampung marriage was a name of custom marriage in Rote Ndao that had been held in past. Now, lots of people are not doing the Terang Kampung marriage, but prefer to marriage officially. The Terang Kampung marriage is sometimes chosen as a way for underage marriage.The belis (dowry) for this Terang Kampung marriage could be paid based on previous agreement, as after the marriage. Whereas for legal marriage the belis (dowry) must be given before wedding. The Terang Kampung marriages are attended by head of the village, maneleo (head of traditional tribe), and parents and families from both sides. The marriages aimed to inform residents that a couple have bond as husband and wife. They are not considered cohabiting, even the marriage has not been registered in the civil registration.

One of the teenager mother's biggest concern about her child related to negative influences from the environment. These could ruin her children's 
future, such as promiscuity that ends in sexual relationship. The informant said to anticipate the negative influences were by advicing repeatedly about 'things that should not be done. Because these could ruin their own future. She said, nowadays even for elementary or the first grade junior high school students could be pregnants as many had got menstruation since elementary school.

"I said to my daughter must protect herself so that nothing 'bad' happened to her. For me, pray is the only key. Without God intervention, everything is vain." DK

\section{DISCUSSION}

There is a proverb "Tomanek Ina Kakanak" or a man is like a king and a woman is like a child in Rote culture. As a king, a man can do anything and make a rule, meanwhile a woman has tasks for housework. There were differences between boys and girls in daily activities. Girls were responsible doing housework as preparing to be wives and mothers. Meanwhile, boys were having freedom as spent leisure activity in the afternoon, and more mobile than girls. Besides, some boys had traditional alcohol 'Sopi' drinking habit. It was possibly influenced by the paternalistic culture in Rote Ndao. Moreover, mobile phones had negative influences of among teenagers as access to porn videos.

In Limakoli village, girls having the first menstruation adviced by their mothers about menstrual care, taboos about menstruation, and not to bring male friends to their rooms. Knowledge of reproductive health were from junior high school, the Pastor of Church in Limakoli Village gave brief explanation of the teenagers' lives. Meanwhile, boys got the information from peers, siblings, and television but sometimes giving misinformation. Information of sexual and reproductive health on the risk of sexual behavior were limited (Krugu et al., 2017).

Some teenagers in Limakoli village started dating, and several had sexual relations possibly because lack of parents's supervision since they worked all day. Besides, many junior/senior high school students lived apart in the neighboring village (Wado, Sully and Mumah, 2019). Parental guides and supervision could lower risk of sexual behavior that ended in teenage pregnancy (Beguy, Ndugwa and Kabiru, 2013). In fact, parents involvement in communication about sexual reproductive health could delay adolescent sexual activities and early pregnancies (Silk and Romero,
2016). Culturally, discussing sexual and reproductive health are still considered as uncomfortable and embarrassing topics.

There was stigma in adolescent pregnancy (Udmuangpia et al., 2017). The stigma of unwanted pregnancies caused ostracized by friends, family, and community (Udmuangpia et al., 2017) or fear reactions for parents, families, friends, shame and embarrassment, and could have resulted in unsafe abortion (Osok et al., 2018; Cense and Ganzevoort, 2019). Three teenagers out of wedlock pregnancies were not easily accepted by parents. In this study, he out of marriage pregnant teenagers were being "punished" such as family anger, be gossip in their villages as the teenager who had abortion. It was similar to study by Aziato as one of the informant's parents were very angry (Aziato et al., 2016). She run to her brother house in a neighboring village because so afraid and tried for abortion. Though the fetus was alive, her mother took to a traditional healer for stomach massage which caused bleeding. The bleeding which led to abortion was risk to death (Munakampe, Zulu and Michelo, 2018). In Ghana, highly educated pregnant teenagers tended to have an abortion (Biney and Nyarko, 2017).

For teenager with the second pregnancy, she covered up her first pregnancy from the family, school, and friends. It was as a coping method in teenage pregnancies (Kaye, 2008). During study, her underfive child was raised by her parents' child. It was similar in Nairobi, Kenya, where parents accepted their child's pregnancy, gave family name to their grandchild, and considered their own child (Osok et al., 2018).

The sexual relations caused teenagers pregnancies become important attention because they are physically and psychologically immature. They were risks for anemia, pregnancy-induced hypertension, infection, deaths while their infants had chances to suffer from deaths and infections (Christofides et al., 2014). These were leading to risk degradation, diseases and deaths through abortion (Tagoe-darko, 2013). Moreover, childbearing out of wedlock resulted in lack support of family which cause abortion (Tagoe-darko, 2013).

The other burdens of teenager pregnancies were mental health. In this study, the teenager who had abortion was quiet. Pregnant teenagers experienced sadness, depression, and regret In Ghana, while boys denial pregnancy or suggest abortion girls (Aziato et al., 2016). Studies in Ghana, Uganda, and Kenya 
showed pregnant teens experience depression, anxiety and stress (Aziato et al., 2016; Kaye, 2008; Osok et al., 2018). Depression could affect to the serious risk of pregnancy, birth outcomes, repeat childbearing, and parenting (Corcoran, 2016) as no social support (Lockwood Estrin et al., 2019).

Teenager pregnancies linked to psychological effect and affected to the psychological development of the child (Alabi and Oluwafemi, 2017). The other teenager's childcare responsibility were parents handed over by her parent. It was because she was not ready to have children, low knowledge about parenting and child care. Teenagers had higher levels of parenting stress (Bahk et al., 2015). Getting support from surrounding and close related persons had a positive effect on their mental health (Peter et al., 2017).

Here, they dropped out of school and tended not to get along with her schoolmates as studies in Tanzania Ghana, Uganda, and Kenya (Maluli and Bali, 2014; Kaye, 2008); Osok et al., 2018). The young men left young women and continued their education. This was similar to a study in rural region in Victoria, Australia (Connor, Edvardsson and Spelten, 2018). Whereas in Northern Malawi, being out of school for girls were associated with early sexual activity, pregnancy and marriage, but not for the boys (Glynn et al., 2018). Most of pregnant teenagers got lower educational achievement because could not finish their education, though back to school (Shahidul and Karim, 2015), and still depended on their parents. They had impacts like job loss, marital disruptions, shock to households (Grant and Hallman, 2008).

The second pregnant adolescent showed low bargaining power of women. Meanwhile, Sari showed bargaining power of women in a low relationship resulted in violence dating (Sari, 2012). Violence dating cases in Afro American ethnic groups were related to unhealthy behavior that leads to be unwanted pregnancies, Sexually Transmitted Diseases and HIV infection (Wingood et al., 2001). No violence dating and HIV-AIDS cases was reported in Limakoli village.

The previous delivery of pregnant teenager in this village was assisted by traditional birth attendances as common. It was similar to a study in Southeast Ethiopia (Belda and Gebremariam, 2016). Having birth at home was considered practical. Moreover, the TBA's were thought to be experienced, close by them, and their families during labor process. Actually, the policy of East Nusa Tenggara Province Health
Office is all labors should be at the PHC, because health staffs, equipments for basic obstetric neonatal services, and ambulance for emergencies were available (Dinas Kesehatan Provinsi NTT, 2009).

Home services was crucial in maternal and health programmes (Serbanescu et al., 2019). As a study by Raj et al, the pregnant teenagers here had low antenatal care (Raj et al., 2010). Pregnant teenagers were afraid to access antenatal service due to fear of stigma (Rukundo et al., 2019). They also cause denial pregnancy and lack of treatment because did not carry out antenatal care in Kenya (Osok et al., 2018). For pregnant teenagers include feelings of insecurity for their future, defeat and sadness with their pregnancy, and not getting support and helplessness in providing care for their babies (Osok et al., 2018). A study in Canada explained how women plan their birth experiences and to negotiate these health-related decisions (Cook and Loomis, 2012).

One of pregnant teenagers had Terang Kampung marriage and moved to her parents in law's house in neighboring village. She would marry officially after giving birth. Whereas the "position" of women who were pregnant but then carry out Terang Kampung marriages, tended not to be gossip. She had antenatal care at the Integrated Health Post and planned and to give birth at the PHC. Maybe she was not ashamed to access health services because had been married, similar to a study in Ghana (Gyan, 2018). However, Terang Kampung marriages were likely not done by pregnant teenagers because including parents and extended families. In Aceh Province, marriages among underages are by applying the dispensation of marriage to the Religious Affairs Office (Fitrianti, 2012).

Sex education by school could reduce cases of premarital sex and adolescent pregnancies in Tanzania (Jukes, Simmons and Bundy, 2008; Lyimo, Masinde and Chege, 2017). Meanwhile, Edmeades et al showed sexual and reproductive health program to very young adolescents for sustainable outcomes which should involve parents, teachers, religious leaders, gatekeeper and other mentors, and promoted gender-transformative programs (Edmeades et al., 2012). There was an intervention involving mid and macro level influences (Igras et al., 2014). An intervention was for reducing violence against adolescent girls, providing education, health care, and funding assistance in Kenya (Austrian et al., 2016). In South Africas one of refining strategies 
to unplanned pregnancies, boys must engage in the sexual education (Odimegwu, Amoo and Wet, 2018). Furthermore, Osok showed an integrated adolescent health services with mental health (Osok et al., 2018).

Pregnant teenagers in Limakoli village had physical, phychological, social risks, hence a sociocultural intervention need to be implemented. It should develop dating with no sexual relations, no adolescence pregnancies, and no adolescence marriage. There should be holistic and integrative approach to provide knowledge about adolescence and reproductive health involving adolescents, parents, teachers, health workers and health institutions, religious leaders, traditional leaders, the head of village (Sari, Handayani, Yolanda, 2019). Schools can give education about reproduction system; the church for sexual relations and marriage from religious bases; the PHC for comprehensive health services of reproductive, maternal and mental health; traditional leaders for revitalization of the tradition marriage; and also village officials for marriage according to age.

\section{CONCLUSIONS}

There were differences of teenager behaviors in which girls were responsible for houseworks, meanwhile boys spent leisure times in the afternoon. There was stigma for pregnant in Limakoli village. Pregnant teenagers ended in abortion, second pregnancy, and had traditional marriage. The abortion was risk of bleeding. The pregnant girls who had abortion became quiet, whereas the teenager with second pregnancy was likely to cover her pregnancy. The teenager with second pregnancy was supported by her parents, whereas the teenager who had traditional marriage lived with her mother in law. Pregnant teenagers had low antenatal care. The pregnant teenagers dropped out from school, in contrast the boys.

A intervention should develop dating with no sexual relations, no adolescence pregnancies, and no adolescence marriage. There should be holistic and integrative approach to provide knowledge about adolescence and reproductive health involving adolescents, parents, teachers, health workers and health institutions, religious leaders, traditional leaders, the head of village

\section{SUGGESTIONS}

It suggests an integrative sociocultural intervention for dating with no sexual relations, no adolescence pregnancies and marriage among school, church, primary health center, traditional leaders, village staffs should be developed.

\section{ACKNOWLEDGMENTS}

We would like to acknowledge the contribution of Dusri Lens Messah of local researcher who was instrumental to the data collection process.

\section{REFERENCES}

Alabi, O. T. and Oluwafemi, I. 2017. 'Teenage Pregnancy in Nigeria : Causes, Effect and Control', International Journal of Academic Research in Business and Social Sciences, 7(2), pp. 17-32. https://doi.org/10.6007/ IJARBSS/v7-i2/2610.

Austrian, K., Muthengi, E., Mumah, J., Soler-Hampejsek, E., Kabiru, C. W., Abuya, B. and Maluccio, J. A. 2016. 'The Adolescent Girls Initiative-Kenya (AGI-K): study protocol', BMC Public Health, 16(210), pp. 1-14. https://doi.org/10.1186/s12889-016-2888-1.

Aziato, L., Hindin, M., Maya, E., Manu, A., Amuasi, S., Lawerh, R. and Ankomah, A. 2016. 'Adolecents' Responses to an Unintended Pregnancy in Ghana: a Qualitative Study', J Pediatr Adolesc Gynecoll, 29(6), pp. 653-658. https://doi.org/10.1016/j. jpag.2016.06.005.

Badan Litbangkes. 2008. Laporan Riskesdas 2007. Jakarta.

Badan Litbangkes. 2015. Laporan Riskesdas 2013. Jakarta.

Bahk, J., Yun, S., Kim, Y. and Khang, Y. 2015. Impact of Unintended Pregnancy on Maternal Mental Health : A Causal Analysis using Follow Up Data of the Panel Study on Korean Children ( PSKC )', BMC Pregnancy and Childbirth, 15(85), pp. 1-12. https:// doi.org/10.1186/s12884-015-0505-4.

Beguy, D., Ndugwa, R. and Kabiru, C. W. 2013. 'Entry Into Motherhood Among Adolescent Girls in Two Informal Settlements in Nairobi, Kenya', J Biosoc Sci, 45(6), pp. 721-742. https://doi.org/10.1017/ S0021932013000199.

Belda, S. S. and Gebremariam, M. B. 2016. 'Birth Preparedness, Complication Readiness and Other Determinants of Place of Delivery among Mothers in Goba District, Bale Zone, South East Ethiopia', BMC Pregnancy and Childbirth, 16, pp. 1-12. https://doi. org/10.1186/s12884-016-0837-8. 
Biney, A. A. and Nyarko, P. 2017. 'Is a Woman's First Pregnancy Outcome Related to Her Years of Schooling? An Assessment of Women's adolescent Pregnancy Outcomes and Subsequent Educational Attainment in Ghana', Reproductive Health, 14(123), pp. 1-15. https://doi.org/10.1186/s12978-0170378-2.

BKKBN, BPS and Kementerian Kesehatan. 2018. Survei Demografi dan Kesehatan Indonesia 2017 Buku Remaja. Jakarta.

Cense, M. and Ganzevoort, R. R. 2019. 'The Storyscapes of Teenage Pregnancy. On Morality, Embodiment, and Narrative Agency', Journal of Youth Studies, 22(4), pp. 568-583. https://doi.org/10.1080/136762 61.2018.1526373.

Christofides, N. J., Jewkes, R. K., Dunkle, K. L., Mccarty, F., Shai, N. J., Nduna, M. and Sterk, C. 2014. 'Risk Factors for Unplanned and Unwanted Teenage Pregnancies Occurring Over Two Years of Follow-up among a Cohort of Young South African Women', Global Health Action, 7(1). https://doi.org/10.3402/ gha.v7.23719.

Connor, S., Edvardsson, K. and Spelten, E. 2018. 'Male Adolescents' Role in Pregnancy Prevention and Unintended Pregnancy in Rural Victoria : Health Care Professional's and Educators' Perspectives', BMC Pregnancy and Childbirth, 18(245), pp. 1-10.

Cook, K. and Loomis, C. 2012. 'The Impact of Choice and Control on Women's Childbirth Experiences', $J$ Perinat Educ, 21(3), pp. 158-168. https://doi. org/10.1891/1058-1243.21.3.158.

Corcoran, J. 2016. 'Teenage Pregnancy and Mental Health', Societies, 6(21), pp. 1-9. https://doi.org/10.3390/ soc6030021.

Daradjat, Z. 1990. Kesehatan Mental. Jakarta: CV Haji Mas Agung.

Dinas Kesehatan Provinsi NTT. 2009. Pedoman Revolusi KIA di Provinsi NTT. Kupang: Dinas Kesehatan Provinsi NTT.

Edmeades, J., Hayes, R., Hollingworth, G. and Warner, A. 2012. The Girl Effect: What do Boys Have to do with it? Meeting Report. Washington, DC.

Fitrianti, Y. 2012. Buku Seri Etnografi Kesehatan Ibu dan Anak:Etnik Gayo, Desa Tetingi, Kecamatan Blang Pegayon, Kabupaten Gayo Lues, Provinsi NAD. Jakarta: Badan Litbangkes.

Glynn, J. R., Sunny, B. S., Destavola, B., Dube, A., Chihana, M., Price, A. J. and Crampin, A. C. 2018. 'Early School Failure Predicts Teenage Pregnancy and Marriage: A Large Population- based Cohort Study in Northern Malawi', PLoS ONE, 92, pp. 1-17.

Grant, M. and Hallman, K. 2008. 'Pregnancy-Related School Dropout and Prior School Performance in KwaZuluNatal, South Africa', Stud Fam Plann, 39(36982).

Gyan, S. E. 2018. 'Passing as "Normal ": Adolescent Girls ' Strategies for Escaping Stigma of Premarital Sex and
Childbearing in Ghana', Sage Open, 8(3), pp. 1-8. https://doi.org/10.1177/2158244018801421.

Igras, S. M., Macieira, M., Murphy, E. and Lundgren, R. 2014. 'Investing in Very Young Adolescents' Sexual and Reproductive Health', Global Public Health, 9(5), pp. 555-569. https://doi.org/10.1080/17441692.201 4.908230 .

Jukes, M., Simmons, S. and Bundy, D. 2008. 'Education and Vulnerability : The Role of Schools in Protecting Young Women and Girls from HIV in Southern Africa', AIDS, 22, pp. S41-S56.

Kaye, D. K. 2008. 'Negotiating the Transition from Adolescence to Motherhood: Coping with Prenatal and Parenting Stress in Teenage Mothers in Mulago Hospital, Uganda', BMC Public Health, 8(83). https:// doi.org/10.1186/1471-2458-8-83.

Krugu, J. K., Mevissen, F., Munkel, M. and Ruiter, R. 2017. 'Beyond Love: A Qualitative Analysis of Factors Associated with Teenage Pregnancy among Young Women with Pregnancy Experience in Bolgatanga Ghana', Cult Health Sex, 19(3), pp. 293-307. https:// doi.org/10.1080/13691058.2016.1216167.

Lockwood Estrin, G., Ryan, E. G., Trevillion, K., Demilew J., Bick, D., Pickles, A. and Howard, L. M. 2019. 'Young Pregnant Women and Risk for Mental Disorders: Findings from an Early Pregnancy Cohort', BJPsych Open, 5(2), pp. 1-7. https://doi.org/10.1192/ bjo.2019.6.

Lyimo, W. J., Masinde, J. M. and Chege, K. G. 2017. 'The Influence of Sex Education on Adolescents' Involvement in Premarital Sex and Adolescent Pregnancies in Arusha City, Tanzania', IJEPRR, 4(6), pp. 113-124. doi: https://doi.org/10.15739/ IJEPRR.17.013.

Maluli, F. and Bali, T. 2014. 'Exploring Experiences of Pregnant and Mothering Secondary School Students in Tanzania', Research on Humanities and Social Sciences, 4(1), pp. 2222-2863.

Mccleary-sills, J., Douglas, Z., Rwehumbiza, A., Hamisi, A. and Mabala, R. 2013. 'Gendered Norms, Sexual Exploitation and Adolescent Pregnancy in Rural Tanzania', RHM, 21(41), pp. 97-105. https://doi. org/10.1016/S0968-8080(13)41682-8.

Munakampe, M. N., Zulu, J. M. and Michelo, C. 2018. 'Contraception and Abortion Knowledge, Attitudes and Practices Among Adolescents from Low and Middle-income Countries: A Systematic Review', BMC Health Services Research, 5, pp. 1-13.

Odimegwu, C. O., Amoo, E. O. and Wet, N. De. 2018. 'Teenage Pregnancy in South Africa: Where Are the Young Men Involved ?', S Afr J Child Health, 12(2 Suppl 1), pp. S44-S50. https://doi.org/10.7196/ SAJCH.2018.v12i2.1523.

Osok, J., Kigamwa, P., Huang, K., Grote, N. and Kumar, M. 2018. 'Adversities and Mental Health Needs of Pregnant Adolescents in Kenya: Identifying 
Interpersonal, Practical, and Cultural Barriers to Care', BMC Women's Health, 18(1), pp. 1-18. https:// doi.org/10.1186/s12905-018-0581-5.

Peter, P. J., de Mola, C. L., de Matos, M. B., Coelho, F. M., Pinheiro, K. A., da Silva, R. A., Castelli, R. D., Pinheiro, R. T. and Quevedo, L. A. 2017. 'Association between Perceived Social Support and Anxiety in Pregnant Adolescents', Revista Brasileira de Psiquiatria, 39(1), pp. 21-27. https://doi.org/10.1590/1516-4446-20151806.

Raj, A. D., Rabi, B., Amudha, P., R, V. T. E. and Glyn, C. 2010. 'Factor Associated with teenage Pregnancy in South Asia: A Systematic Review', Health Science Journal, 4(1), pp. 3-14.

Romauli, S. 2011. Buku Ajar Asuhan Kebidanan dan Konsep Dasar Asuhan Kehamilan. Yogyakarta: Nuha Medika.

Rukundo, G., Abaaasa, C., Natukunda, P. and Allain, D. 2019. 'Parents' and Caretakers' Perceptions and Concerns about Accessibility of Antenatal Services by Pregnant Teenagers in Mbarara Municipality, Uganda', Midwifery, 72, pp. 74-79.

Sari, S. N. 2012. Perilaku Seksual dan Faktor yang Berhubungan Pada mahasiswa S1 Reguler Fakultas X Universitas Indonesia Tahun 2012. Universitas Indonesia.

Serbanescu, F., Goodwin, M. M., Binzen, S., Morof, D., Asiimwe, A. R., Kelly, L., Wakefield, C., Picho, B., Healey, J., Nalutaaya, A., Hamomba, L., Kamara, V., Opio, G., Kaharuza, F., Blanton, C., Luwaga, F. and Steffen, M. 2019. 'Addressing the First Delay in Saving Mothers, Giving Life Districts in Uganda and Zambia : Approaches and Results for Increasing Demand for Facility Delivery Services Three Delays That Contribute to Maternal Mortality', Global Health: Science and Practice, 7, pp. 48-67.
Shahidul, S. M. and Karim, A. H. M. Z. 2015. 'Factors Contributing to School Dropout Among the Girls: A Review of Literature', European Journal of Research and Reflection in Educational Sciences, 3(2), pp. 25-36.

Silk, J. and Romero, D. 2016. 'The Role of Parents and Families in Teen Pregnancy Prevention : An Analysis of Programs and POlicies', Journal of Family Issues, 35(10), pp. 1339-1362. https://doi. org/10.1177/0192513X13481330.

Soejoenoes, A. 2017. 'Tenage Pregnancy', INAJOG, 5(3), pp. 128-129. https://doi.org/10.32771/inajog.v5i3.

Spradley, J. P. 2007. Metode Etnografi. Yogyakarta: Tiara Wacana.

Tagoe-darko, E. 2013. "'Fear, Shame and Embarrassment": The Stigma Factor in Post Abortion Care at Komfo Anokye Teaching Hospital, Kumasi, Ghana', Asian Journal Science, 9(10), pp. 134-141. https://doi. org/10.5539/ass.v9n10p134.

Udmuangpia, T., Nordin, E. H.-, Worawong, C., Tanglakmankhonge, K. and Bloom, T. 2017. 'A Qualitative study : Perceptions Regarding Adolescent Pregnancy Among A Group of Thai Adolescents in Sweden', Pacific Rim Int J Nurs Res, 21(1), pp. 75-87.

Wado, Y. D., Sully, E. A. and Mumah, J. N. 2019. 'Pregnancy and Early Motherhood Among Adolescents in Five East African Countries: A Multi-Level Analysis of Risk and Protective factors', BMC Pregnancy and Childbirth, 19(59), pp. 1-11.

WHO. 2004. Adolescent Pregnancy Issues in Adolescent Health and Development. Geneva.

Wingood, G., DiClemente, R., McCree, D., Harrington, K. and Davies, S. 2001. 'Dating Violence and the Sexual Health oh Black Adolescent Females', Pediatrics, 107(5), pp. 1-4. doi: https://doi.org/10.1542/ peds.107.5.e72. 